\title{
Morganella morganii, Lysine-Positive
}

National Cancer Institute

\section{Source}

National Cancer Institute. Morganella morganii, Lysine-Positive. NCI Thesaurus. Code C123521.

Any bacterial species identified as Morganella morganii that can metabolize lysine. 